\title{
Surgical Findings and Results of Stapes Surgery for Stapedial Fixation in Adults
}

\author{
Ho-Seob Kang ${ }^{1}$, Je Yeon Lee ${ }^{1}$, Myung Hoon Yoo ${ }^{2}$, and Hong Ju Park ${ }^{1}$ \\ ${ }^{\prime}$ Department of Otolaryngology, Asan Medical Center, University of Ulsan College of Medicine, Seoul; and \\ ${ }^{2}$ Department of Otorhinolaryngology-Head and Neck Surgery, Korea University Ansan Hospital, Ansan, Korea
}

\section{성인 등골고정증 환자의 등골수술 소견과 청력검사 결과}

강호섭 ${ }^{1} \cdot$ 이제연 ${ }^{1} \cdot$ 유명훈 $^{2} \cdot$ 박홍주 $^{1}$

울산대학교 의과대학 서울아산병원 이비인후과학교실, ${ }^{1}$ 고려대학교 의과대학 안산병원 이비인후과학교실 2

\author{
Received January 24, 2015 \\ Revised March 24, 2015 \\ Accepted March 27, 2015 \\ Address for correspondence \\ Hong Ju Park, MD, PhD \\ Department of Otolaryngology, \\ Aasan Medical Center, \\ University of Ulsan \\ College of Medicine, \\ 88 Olympic-ro 43-gil, Songpa-gu, \\ Seoul 138-736, Korea \\ Tel $+82-2-3010-3710$ \\ Fax $+82-2-489-2773$ \\ E-mail dzness@amc.seoul.kr
}

Background and Objectives Stapes surgery has been reported to improve hearing for stapedial fixation. This study aimed to review the surgical findings and hearing results of stapes surgeries for 20 ears with stapedial fixation.

Subjects and Method We reviewed the medical records and video recordings of 20 consecutive stapes surgeries between 2011 and 2014. Patient age ranged from 20 to 64 years, representing 5 males and 12 females. Mean audiologic follow-up duration was 11 months. Hearing improvement at the final pure-tone audiometry was determined to be successful when air-bone gap (ABG) was reduced to $20 \mathrm{~dB}$ or less, and excellent when $\mathrm{ABG}$ was reduced to $10 \mathrm{~dB}$ or less. Surgery-related deterioration of bone-conduction $(\mathrm{BC})$ was determined to be positive when the difference between final and preoperative $\mathrm{BC}$ was more than $15 \mathrm{~dB}$, and over-closure positive when final air-conduction (AC) was better than preoperative $\mathrm{BC}$.

Results Pre-operative threshold frequency for $\mathrm{BC}$ and $\mathrm{AC}$ were $39.8 \pm 15.8$ and $66.4 \pm 15.3$ $\mathrm{dB}$ HL, respectively, and ABG was $26.6 \pm 10.2 \mathrm{~dB}$. After the stapes surgery, the thresholds for $\mathrm{BC}$ and $\mathrm{AC}$ were $36.8 \pm 16.3$ and $42.0 \pm 16.2 \mathrm{~dB}$ HL, respectively, and $\mathrm{ABG}$ was $5.2 \pm 6.5 \mathrm{~dB}$ during the last follow-up. After surgery, $\mathrm{BC}$ threshold was significantly improved at $2 \mathrm{kHz}$, whereas $\mathrm{AC}$ threshold improved at all frequencies. Excellent hearing improvement was accomplished in 16 ears (80\%) and successful improvement in all ears (100\%). Over-closure was observed in 7 ears (35\%). There were no patients with surgery-related sensorineural hearing loss.

Conclusion Stapes surgery is effective for improving hearing for stapedial fixation. Operator should be able to cope with various situations during or after the stapes surgery.

Korean J Otorhinolaryngol-Head Neck Surg 2015;58(7):469-74

Key Words Stapedectomy $\cdot$ Stapedotomy $\cdot$ Stapes surgery.

\section{서 론}

성인에서 등골고정을 유발하는 가장 흔한 질환인 이경화증 은 서양에서는 사후 시행한 병리학적 검사의 $6.4 \%$ 에서 나타 나며, 전농 환자의 $47 \%$ 는 이경화증에 의해 발생된다고 보고 된다. 1) 1952년 Rosen ${ }^{2}$ 이 등골가동술(mobilization)을 시행 하여 청력이 성공적으로 회복된 이후 현대적 등골수술이 시 작되었으며, 1956년 Shea ${ }^{3)}$ 가 이경화증 환자에게 등골절제술 (stapedectomy)을 시행한 이후로 수술기구와 수술방법이 크 게 개선되었으며 등골수술을 통해 성공적인 청력 회복이 가 능함이 입증되었다. 이경화증은 동양인에서는 드문 질환으 로, 국내의 경우 등골고정에 대한 수술 결과에 대한 발표는 드문 실정이다. ${ }^{4-6)}$ 본 연구의 목적은 등골고정이 발생한 20귀 에 대해 수술 소견과 청력검사 결과를 분석하여 등골수술의 청각학적 결과를 보고하고 등골수술의 시행 시 고려해야 할 사항을 살펴보고자 하는 것이다. 


\section{대상 및 방법}

2011년 6월부터 2014년 6월까지 약 3년간 정상 고막소견을 보이는 전음성 난청으로 1 인 술자에 의해 시험적 고실개방술 후 등골수술을 받은 모든 증례인 20귀(17명)를 대상으로 하 였다. 수술 전 임상정보와 수술 전후의 청력변화 양상 등을 의무기록을 통해 후향적으로 분석하였다. 수술기록지와 수 술 중 녹화한 영상자료를 통해 접근 방법, 동반된 이소골 기 형, 안면신경의 주행, 사용된 인공삽입물(piston wire)의 고정 위치, 술 후 합병증 등에 대하여 조사하였다. 남자는 5명(5귀, $25 \%)$, 여자는 12 명(15귀, $75 \%)$ 이었으며, 평균연령은 47.6세였다. 추적관찰 기간은 1 개월에서 24 개월로 평균 11.3 개월이었다.

15 명은 청력장애, 2 명은 이명을 주소로 내원하였으며, 9 명 (53\%)에서 양측성을 보였고, 8 명에서 편측성을 보였다. 수술 중 등골이 움직이지 않음을 확인하였을 때 등골고정증으로 진 단하였으며, 20 예의 등골고정증 환자 중 이경화증은 18 예, 나 머지 2예는 이소골 기형을 동반한 선천성 등골고정증으로 진 단되었다. 동반 증상으로 9명에서 이명을, 3명에서 현훈을, 3 명이 이충만감을 호소하였으며, 동반증상이 없는 경우는 4명 이었다. 증상 자각 시부터 본원에 내원하여 수술을 받기까지 경과한 시간은 10 일에서 51 년으로 평균 118 개월이 걸렸다. 1 예 는 전음성 난청으로 타원 및 본원에서 2회의 이소골성형술을 시행받았던 병력이 있었고, 1 예는 전음성 난청으로 타원에서 등골절개술을 시행받았던 병력이 있었으며, 1 예는 상반고리 관피열 증후군으로 중두개와 접근법을 통한 수술을 시행받 았던 병력이 있었다.

모든 환자에서 국소마취 하에 이내접근(endaural approach) 을 사용하였다. 등골족판의 노출을 위해 수술창을 충분히 포 함하도록 고려하여 고실외이도피판(tympanomeatal flap)을 거상한 후 골성 외이도의 후상방을 제거하여 안면신경의 고실 분지와 추체융기(pyramidal eminence)가 노출되게 하였다. 등 골근건, 등골 후각과 전각의 순서로 절제를 하여 등골족판 을 노출하였다. 모든 환자에서 $0.4 \sim 0.6 \mathrm{~mm}$ 굵기의 인공삽입 물(piston wire, Medtronic Xomed, Jacksonville, FL, USA) 을 사용하여 이소골 연쇄를 복원하였으며, 등골절개술은 이 보다 $0.2 \mathrm{~mm}$ 더 큰 드릴버(bur)를 사용하여 개창술을 시행하 였다. 인공삽입물의 길이는 등골절개술을 시행하기 전에 미리 침골장각 내측과 등골족판 사이의 거리를 측정하여 인공삽 입물의 길이를 조정하고 이를 실제로 수술창에 넣어서 인공삽 입물이 등골의 안쪽으로 약 $0.2 \mathrm{~mm}$ 정도 들어갈 수 있는 길이 로 추가로 재단하여 사용하였다 $(3.5 \sim 5.5 \mathrm{~mm}$, 평균 $4.2 \mathrm{~mm})$. 이내접근을 할 때 노출되는 연부조직을 미리 채취하고 재단 하여 수술 후 등골개창술 주위를 둘러싸며 막아 외림프액의
누출을 방지하였으며, 등골절제술의 경우에는 연부조직이 개창을 통해 내이로 들어가지 않도록 보다 큰 크기의 연부조 직을 재단하여 사용하였다. 모든 환자에서 인공삽입물을 삽 입 후 고실외이도피판을 제자리에 위치하여 환자의 주관적 인 청력의 호전을 확인한 후 외이도를 젤폼(gelfoam)으로 채 운 후 수술을 종료하였다.

수술 전후 청력의 변화는 대한이비인후과학회지에 발표된 수술 후 청력 결과 보고 표준 지침에 따라 $0.5,1,2,3 \mathrm{kHz}$ 네 주파수에서의 순음청력역치를 이용하여 계산하였다.5) $3 \mathrm{kHz}$ 골도청력역치가 없는 경우 $2 \mathrm{kHz}$ 와 $4 \mathrm{kHz}$ 의 평균을 구하여 $3 \mathrm{kHz}$ 를 대신하였다. 성공적인 수술은 수술 후 마지막 순음 청력검사에서 기도-골도청력역치의 차이가 $20 \mathrm{~dB}$ 이내로 감 소한 경우를 성공적인 청력호전(successful hearing improvement), $10 \mathrm{~dB}$ 이내로 감소한 경우를 훌륭한 청력호전(excellent hearing improvement)으로 정의하였다.) 수술 후의 골 도청력역치가 수술 전의 골도청력역치보다 $15 \mathrm{~dB}$ 이상 악화되 었을 경우에 골도청력의 악화로 정의하였다. 수술 전 골도청력 역치보다 수술 후 기도청력역치가 더 호전될 경우 overclosure 로 정의하였다.

통계 처리는 Wilcoxon signed ranks test를 이용하여 $p<$ 0.05 인 경우 통계적으로 유의하다고 판정하였다.

\section{결 과}

본 연구에서는 모든 환자에서 일차적으로 등골절개술을 시도하였으나, 2예의 환자에서 등골 후각을 제거할 때 의도치 않게 등골족판의 골절이 발생하여 등골절제술을 시행하였다. 이외의 18 예 모두에서 등골절개술을 시행하였다.

대부분의 환자에서 침골장각을 이용하여 이소골 연쇄를 재 건할 수 있었으나, 침골장각을 이용할 수 없었던 1예가 있었다. 이 환자는 전음성 난청으로 두 차례 이소골성형술을 받았으 나 청력호전이 없었으며, 이전 수술로 인해 침골은 제거된 상 태였다. 따라서, 이 환자의 경우에는 추골병을 이용하여 이소 골 연쇄를 재건하였다(Fig. $1 \mathrm{~A}$ and B). 다른 1 예의 환자에서 는 안면신경이 정상에 비해 하방으로 주행하며 수술 중 골 결 손을 통한 안면신경의 부종이 발생하여 등골의 노출이 충분 하지 않았으며, 안면신경을 피해 등골족판의 전하방(anteroinferior) 부분에 등골절개를 시행한 후에 인공구조물을 이 용하여 이소골 연쇄를 재건하였으며, 이때 필연적으로 인공구 조물이 안면신경과 접촉하게 되었으나, 수술 후 청력역치에는 큰 영향을 주지 않았다(Fig. 1C and D).

타원에서 등골절개술을 시행받은 후 청력호전 되었으나 이 후 청력저하가 재발한 1 예에서는 수술 전 시행한 CT에서 인 
공삽입물의 전위가 관찰되었으며 수술 중 전위된 보형물을 제거하고 새로운 인공구조물을 이용하여 성공적인 이소골 연쇄 재건이 가능하였다.

\section{수술 전후의 순음청력검사 결과}

수술 전 순음청력검사에서 기도청력역치는 $66.4 \pm 15.3 \mathrm{~dB}$ $\mathrm{HL}$, 골도청력역치는 $39.8 \pm 15.8 \mathrm{~dB} \mathrm{HL}$, 기도골도청력차(air-

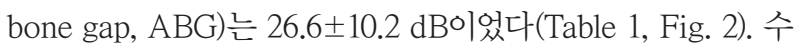

술 후 마지막 측정한 순음청력검사에서 기도청력역치는 42.0 $\pm 16.2 \mathrm{~dB} \mathrm{HL}$, 골도청력역치는 $36.8 \pm 16.3 \mathrm{~dB}$ HL이었고 $\mathrm{ABG}$ 은 $5.2 \pm 6.5 \mathrm{~dB}$ 이었다. 수술 후 골도청력역치는 수술 전에 비 해 평균 $2.9 \pm 6.5 \mathrm{~dB}$ 의 골도청력역치의 감소를 보였으며, 각 주파수별로 이를 분석해보면 $2 \mathrm{kHz}$ 에서는 $6.5 \mathrm{~dB}$ 의 호전을 보여 통계적으로 유의한 청력 호전을 보였으나 $(p<0.05), 0.5$, $1,3 \mathrm{kHz}$ 에서는 통계적인 차이는 없었다(Table 1, Fig. 2). 주 파수별 수술 전후의 기도청력역치의 변화를 살펴보면, 0.5
A

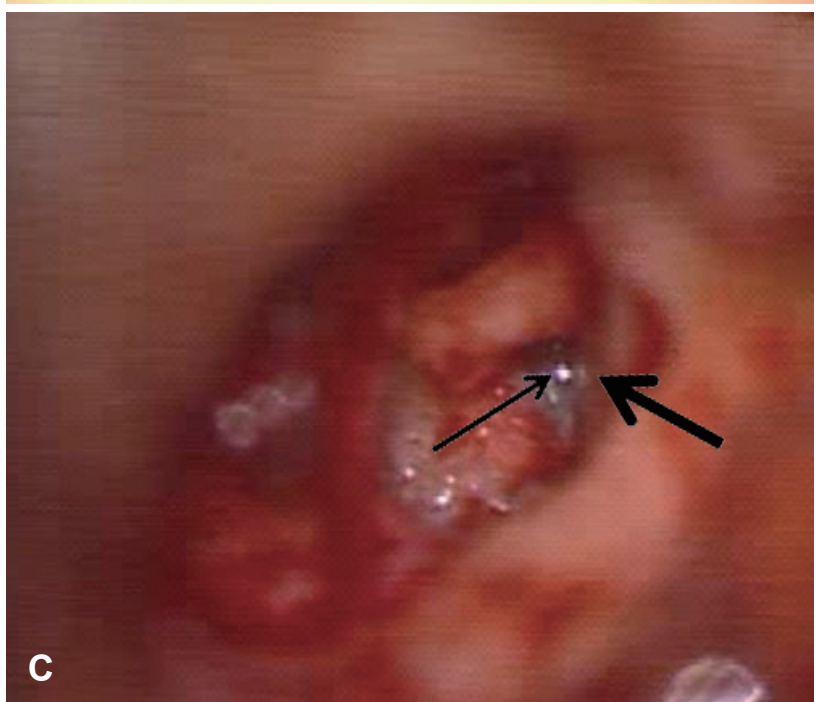

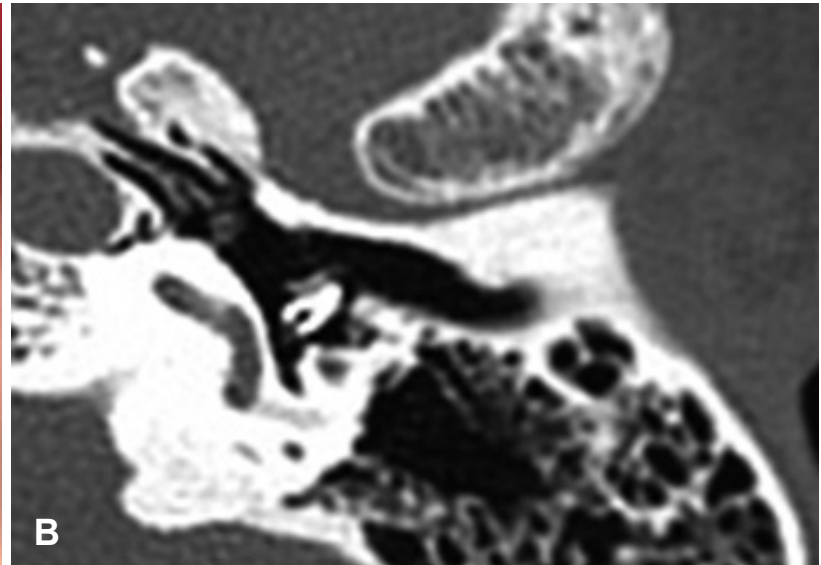

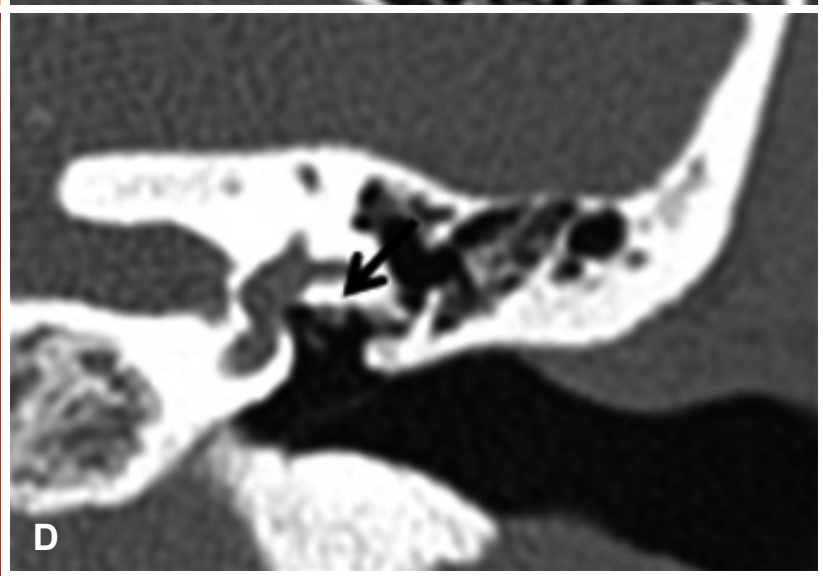

Fig. 1. Malleostapedotomy in a patient without incus (A). In preoperative CT, partial ossicular replacement prosthesis could be found above the stapedial head (B). In another patient with edematous low-lying facial nerve (black bold arrow in $\mathrm{C}$ ) with bony dehiscence, stapedotomy was done in antero-inferior part of the stapedial footplate (black thin arrow in C). In CT scan, facial nerve (arrow) was located near to the stapes (D).

Table 1. Preoperative and postoperative hearing results

\begin{tabular}{|c|c|c|c|c|c|c|}
\hline \multirow{2}{*}{ Frequency $(\mathrm{kHz})$} & \multicolumn{3}{|c|}{ Preoperative } & \multicolumn{3}{|c|}{ Postoperative } \\
\hline & $A C$ & $\mathrm{BC}$ & $A B G$ & $A C$ & $B C$ & $A B G$ \\
\hline 0.5 & $68.5 \pm 11.0$ & $35.3 \pm 13.9$ & $33.2 \pm 11.5$ & $39.8 \pm 14.1$ & $33.8 \pm 12.1$ & $6.0 \pm 6.4$ \\
\hline 1 & $71.3 \pm 16.1$ & $37.8 \pm 16.9$ & $33.5 \pm 14.0$ & $42.0 \pm 16.4$ & $36.3 \pm 17.2$ & $5.7 \pm 4.6$ \\
\hline 2 & $63.8 \pm 17.9$ & $46.0 \pm 17.8$ & $17.8 \pm 11.0$ & $44.6 \pm 16.1$ & $39.5 \pm 17.5$ & $5.1 \pm 6.8$ \\
\hline 3 & $62.0 \pm 19.8$ & $40.0 \pm 18.3$ & $22.0 \pm 11.0$ & $42.0 \pm 18.6$ & $37.9 \pm 18.1$ & $4.1 \pm 7.9$ \\
\hline Mean (SD) & $66.4 \pm 15.3$ & $39.8 \pm 15.8$ & $26.6 \pm 10.2$ & $42.0 \pm 16.2$ & $36.8 \pm 16.3$ & $5.2 \pm 6.5$ \\
\hline
\end{tabular}

AC: air-conduction thresholds, BC: bone-conduction thresholds, $A B G$ : air-bone gaps, SD: standard deviation 
$\mathrm{kHz}$ 에서 $28.7 \mathrm{~dB}, 1 \mathrm{kHz}$ 에서 $29.3 \mathrm{~dB}, 2 \mathrm{kHz}$ 에서 $19.2 \mathrm{~dB}$, $3 \mathrm{kHz}$ 에서 $20.0 \mathrm{~dB}$ 만큼 네 주파수 모두에서 기도청력역치 가 호전되었으며 $(p<0.05)$, 저주파수에서 고주파수에 비해 기 도청력역치의 호전 정도가 큰 경향을 보였다(Table 1, Fig. 2). 술 후 $\mathrm{ABG}$ 가 $10 \mathrm{~dB}$ 이내인 경우가 16 예(80.0\%), $20 \mathrm{~dB}$ 이내 인 경우는 4 예(100\%)로 술 후 $\mathrm{ABG}$ 가 $20 \mathrm{~dB}$ 이내로 감소한 성 공적인 청력호전은 $100 \%, 10 \mathrm{~dB}$ 이내로 감소한 훌륭한 청력 호전은 $80 \%$ 이었다(Table 2).

수술 후 기도와 수술 전 골도청력역치의 차이가 $10 \mathrm{~dB}$ 이내 인 경우가 19예(95\%), $20 \mathrm{~dB}$ 이내인 경우는 1예(100\%)였으 며, 7예(35\%)에서는 수술 후 기도가 수술 전 골도청력역치보 다 더 호전되는 overclosure를 보였다(Fig. 3).

수술 중 청력손상에 대해 알아보기 위해 $0.5,1,2,3 \mathrm{kHz}$ 에 대해 술 전 골도청력역치와 수술 후 골도청력역치의 차이의 평 균을 구하였다. 수술 전후의 골도청력역치의 차이값은 $2.9 \pm 6.5$ $\mathrm{dB}$ 이었다. 술 후 골도청력의 악화를 의미하는 $15 \mathrm{~dB}$ 이상으 로 골도청력역치가 상승한 경우는 없었다.

\section{시간에 따른 청력의 변화}

일반적으로 수술 후 1 개월, 3 개월, 9 개월째 청력검사를 시 행하였으며, 이후 1 년 간격으로 검사를 시행하였다. Fig. 4에

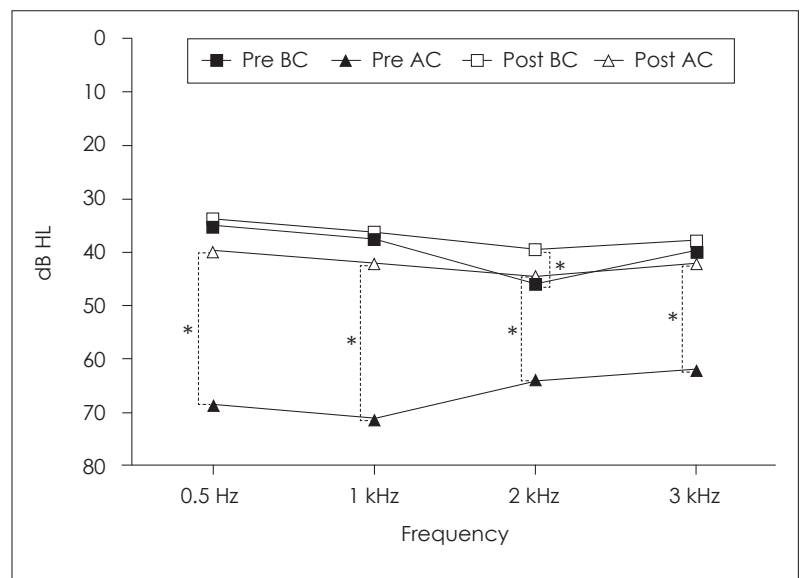

Fig. 2. Air-conduction (AC) and bone-conduction (BC) pure-tone thresholds before and after the stapes surgery. The asterisks indicate a significant difference $(p<0.05)$. There was significant postoperative improvement of $A C$ thresholds at every frequency. BC thresholds showed postoperative improvement only at $2 \mathrm{kHz}$.

Table 2. Changes of $A B G$ before and after surgery $(n=20)$ ABG (dB) Preoperative Postoperative Cumulative rate (\%)

\begin{tabular}{llrr}
-10 & & 16 & 80 \\
$11-20$ & 7 & 4 & 100 \\
$21-30$ & 5 & & \\
$31-40$ & 6 & & \\
$41-50$ & 2 & & \\
\hline
\end{tabular}

ABG: air-bone gaps
서 시간에 따른 모든 환자에서의 청력의 변화를 나타내었으 며, 이 중 8명의 환자에서 술 후 9개월 이상의 청력 결과를 모 든 시기에서 얻을 수 있었다. 술 후 1 개월 기도청력은 평균 34.8 $\mathrm{dB}$ HL이었으며, 술 후 3개월과 9개월은 각각 $30.3,32.8 \mathrm{~dB}$ $\mathrm{HL}$ 로 시간경과에 따른 기도청력의 변화는 술 전과 술 후 1 개 월을 비교하였을 때 유의하였고 $(p=0.012)$, 술 후 1 개월과 술 후 3 개월, 술 후 3 개월과 술 후 9개월의 기도청력은 서로 통계 적으로 유의한 차이를 보이지 않았다(Fig. 4).

\section{합병증}

수술 후 고막천공, 감각신경성 난청의 합병증은 없었다. 수 술 후 심한 체위변환성 어지럼이 발생되어 수일간 호전되지 않

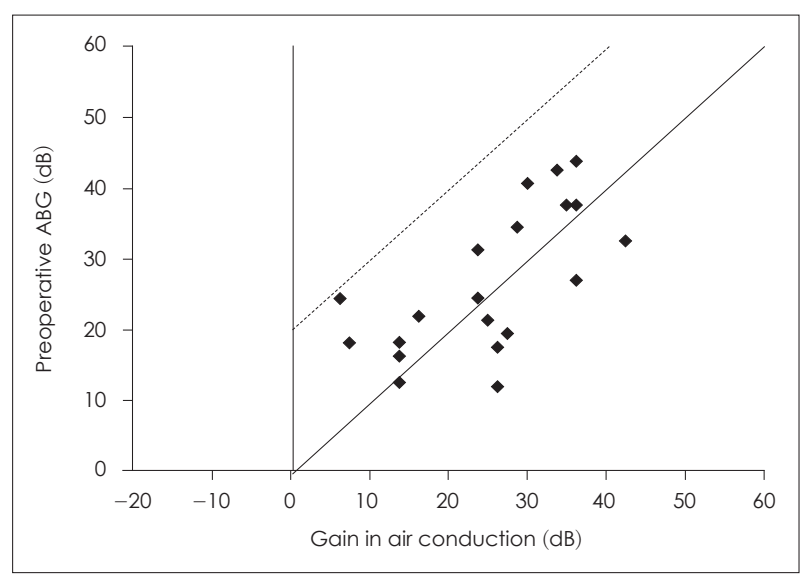

Fig. 3. Audiometric results of 20 cases visualized using the Amsterdam Hearing Evaluation Plots. The solid diagonal line indicates total closure of the gap between preoperative AC and BC. Every point below this line is defined as overclosure. An unsuccessful operation result with regard to $A C$ is defined as a negative change in $A C$ or a change in $A C$ that was not enough to close the gap between postoperative $A C$ and preoperative $B C$ to $20 \mathrm{~dB}$ or less. This is indicated by the dotted diagonal line. AC: air-conduction, $\mathrm{BC}$ : bone-conduction, $\mathrm{ABG}$ : air-bone gap.

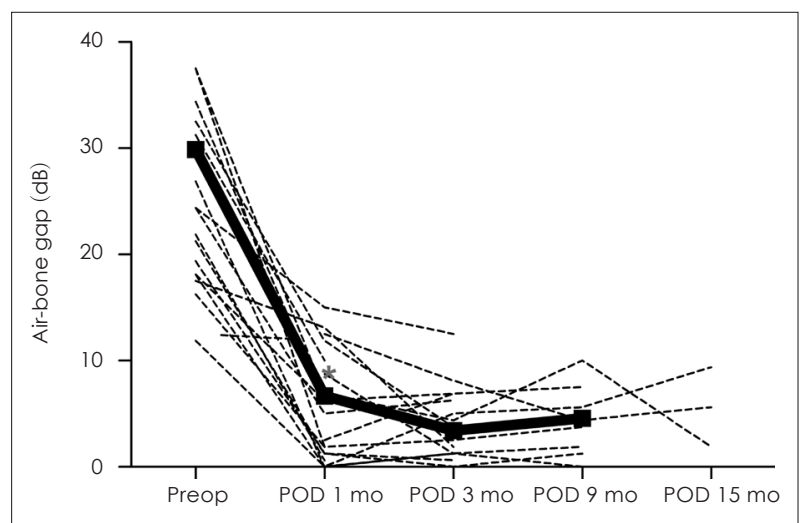

Fig. 4. Change of preoperative and postoperative air-bone gaps over time in each patient. Bold black line represents the mean values of 8 patients who underwent pure-tone tests in all the followup examinations. The asterisk indicates a significant difference $(p<0.05)$. POD: postoperative day. 
아 외림프액 누출이 의심되는 환자가 1 명 $(5 \%)$ 있었으며, 첫 번 째 수술 이후 1 주째 시험적 고실개방술을 다시 시행하였다. 등 골개창부위는 기존 수술에서 넣어둔 연부조직으로 둘러싸여 외림프 누출을 직접적으로 확인하기는 불가능하였으며, 인공 구조물 주변의 연부조직을 제거하고 개창술을 시행한 부위 주위를 연부조직으로 다시 단단히 채웠다. 인공구조물의 길 이가 너무 길어 이석기관을 자극하여 체위성 어지럼증이 발 생할 가능성도 있으므로 등골 내로 들어가는 인공구조물의 길이를 좀 더 짧게 잘라주었다. 수술 후 체위성 현훈은 바로 호전되었고, 골도청력의 변화는 없었다.

\section{고 찰}

본 연구에 참여한 환자들은 평균 11.3 개월 동안 술 후 외래 에서 경과관찰을 하였으며 단기간의 청력검사 결과를 분석하 였다. 문헌상에 수술 후 기도청력역치의 변화는 1년에 0.6 1.2 $\mathrm{dB}$ 정도 변화하는 것으로 알려져 있으며, ${ }^{8)}$ 등골개창술을 시 행한 3050예에서 14년간 정기적으로 시행한 청력검사결과를 분석한 연구에 따르면, 수술 후 발생하는 청력의 악화는 일 반적인 나이에 의한 청력악화와 다르지 않다고 보고된다." 본 연구는 외국 문헌에 비해 관찰기간이 단기간이며 환자의 수는 적으나 모든 환자에서 술 후 1 개월째 시행한 순음청력 검사에서 통계적으로 유의하게 기도청력역치가 호전되었으 며, 기도골도역치차가 감소하였고 이후에 골도나 기도청력역 치 모두 변화가 크지 않고 안정적으로 유지됨을 확인할 수 있 어 외래에 방문하지 않은 환자들에서도 술 후 청력이 유지되 고 있을 것임을 예상할 수 있다.

이번 연구에서 18예에서는 등골절개술(stapedotomy), 2예 에서는 등골절제술(stapedectomy)을 시행하였다. 등골고정 을 치료하기 위해 어떤 수술 기법이 더 합병증이 적고, 효과적 이며 안정된 장기적 청력개선을 보이는가 하는 문제에 대해 많은 연구가 있었지만, $3,8,10-13)$ 등골절개술과 등골절제술의 수 술 성적은 통계적으로 유의한 차이가 없다는 보고가 일반적 이며, ${ }^{811)}$ 등골절개술의 수술 후 합병증이 등골절제술보다 빈 도가 적다는 보고들이 있어 등골절개술이 최근에 흔하게 사 용되는 수술기법이다. 8111

성공적인 등골절개술은 술 후 $\mathrm{ABG}$ 가 $10 \mathrm{~dB}$ 이내로 좁혀진 경우로, 전통적으로 이경화증에서 성공률이 90 95\% 정도로 보고된다. ${ }^{3)}$ 국내의 보고에서 $\mathrm{ABG}$ 가 $10 \mathrm{~dB}$ 이내로 좁혀진 경 우는 41.7 76.9\%, $20 \mathrm{~dB}$ 이내로 좁혀진 경우는 66.6 92.3\%로 보고되고 있고, ${ }^{4-6)}$ 본 연구에서도 $\mathrm{ABG}$ 가 $10 \mathrm{~dB}$ 이내인 경우 는 $80 \%, 20 \mathrm{~dB}$ 이내로 줄어든 경우는 $100 \%$ 로 기존 국내 보 고들과 유사한 성적을 보였다. 성공적인 수술결과를 위해서
는 등골수술에 대한 경험이 중요하며, 특히 등골족판 개창술 과 인공삽입물을 침골에 고정하는 술기에서 경험이 많고 적 음에 따라 차이를 보이는 것으로 알려져 있다. ${ }^{14)}$ 인공삽입물 의 직경에 대한 최근 리뷰에 따르면 $0.6 \mathrm{~mm}$ 의 인공삽입물이 $0.4 \mathrm{~mm}$ 에 비해 성공률이 $67 \%$ 대 $58 \%$ 로 유의하게 좋은 결 과를 보였으며, 술 후 청력 결과들(수술 후 기도골도역치차, 수술 후 기도역치, 기도골도역치차 호전 정도) 역시 $0.6 \mathrm{~mm}$ 가 더 나은 결과를 보였으나, 수술 후 골도역치의 변화는 두 군 간의 차이는 없었다. 따라서 가능하다면 $0.6 \mathrm{~mm}$ 크기의 인 공삽입물을 사용하는 것이 추천된다. ${ }^{15-17)}$

수술 후 부작용으로 $\mathrm{Yoo}$ 와 $\mathrm{Lee}^{4}$ 는 술 후 경도의 일시적 현훈이 12 명 중 6 명(50\%)에서 보였으며 평균 1.8 일 지속되었 고 모두 술 후 2일 내에 호전을 보였다고 보고하였으며, Song 등 ${ }^{5}$ 은 39예 중 9예(23.1\%)에서 술 후 일시적 현훈을 보였고 평균 4.6일간 지속되었으며 대부분은 술 후 2 3일 내에 호전 을 보였다고 보고하였다. Park 등은 7예 중 1예에서 등골족 판에 천공을 가한 후 외림프액이 흘러나왔으나 근막으로 재건 수술을 시행하였고 술 후 감각신경성 난청 혹은 현훈과 같은 합병증은 일어나지 않았음을 보고하였다. 본 연구에서는 외 림프액 누출이 의심되는 경우가 1명(5\%)에서 발생하였으며, 수술 후 지속적인 현훈을 호소하여 시험적 고실개방술을 시 행하였고, 수술창 주위를 다시 연부조직을 이용하여 다시 채 운 후 현훈은 호전되었으며 청력저하는 관찰되지 않았다. 이 외에 안면신경의 하방주행 및 부종으로 등골족판의 노출이 부족하여 인공삽입물이 안면신경과 접촉한 1예가 있었고, 술 후 안면신경 마비는 발생하지 않았다.

본 연구에서는 모든 환자에서 국소마취 하에 등골수술을 시행하였다. 수술은 국소마취와 전신마취 두 가지 방법 모두 가능하며, 국소마취의 경우 수술이 더 짧은 시간 내에 끝나므 로 전신마취에 따른 환자의 부담을 줄일 수 있으며, 현기증의 발생 등 내이 자극을 쉽게 감지할 수 있어 수술 중 발생 가능 한 합병증을 줄이고, 수술 직후 고실외이도피판을 본래의 자 리에 위치시키고 속삭이는 소리 등으로 간단하게 청력 호전의 확인이 가능하다. 최근 리뷰 논문에 따르면 수술 후 $\mathrm{ABG}$, 골 도청력의 악화, 술 후 어지럼증의 발생은 두 마취 방법 간의 차 이는 없었으나, 한 연구에서만 전신마취 하에서 수술 시에 즉 시 농(immediate deaf)의 위험성이 유의하게 높아진다고 보 고하였다. ${ }^{18,19)}$

수술 후 발생할 수 있는 가장 심각한 부작용인 감각신경성 난청은 일차 수술 후 $1 \%$ 미만에서 관찰되며, 심도의 감각신 경성 난청은 매우 드물다( $0.2 \%)$. 이는 술자의 경험, 병변의 침 범 정도, 재발성 증례, 염증이나 메니에르병과 동반된 경우에 발생한다. 대부분은 가벼운 난청이나 고주파에 국한된 난청 
이며, 발견 즉시 스테로이드 치료를 실시한다. ${ }^{20)}$ 수술 후 수일 간의 어지럼증은 흔한 증상이며 점차 호전된다. 어지럼증은 양성발작성체위성현훈에 의해 발생할 수도 있지만, 수주간 지속되는 경우에는 외림프누공, 너무 긴 인공삽입물, 육아종, 중이염 등의 가능성이 있으므로 수술적 치료를 고려해 볼 수 있다. $^{20,21}$

본 연구의 제한점으로는 환자의 수가 적어 인공삽입물의 길이 및 굵기에 따른 청력호전의 정도를 비교할 수 없으며, 경과관찰의 기간이 짧은 점이다. 향후 보다 많은 수의 환자 에서 장기적인 청력검사 결과를 통한 분석이 필요하다.

\section{REFERENCES}

1) Cawthorne T. Otosclerosis. J Laryngol Otol 1955;69:437-56.

2) Rosen S. Mobilization of the stapes to restore hearing in otosclerosis. N Y State J Med 1953;53(22):2650-3.

3) Shea JJ Jr. Forty years of stapes surgery. Am J Otol 1998;19(1):52-5.

4) Yoo MH, Lee KS. Results of primary malleostapedotomy in stapes fixation. Korean J Otorhinolaryngol-Head Neck Surg 2009;52(12): 961-7.

5) Song HM, Choi SJ, Lee KS. Hearing results after stapedotomy in stapes fixation. Korean J Otolaryngol-Head Neck Surg 2007;50(1): 14-8.

6) Park KT, Suh MW, Song JJ, Kim CH, Choi IJ, Kim DW, et al. Clinical manifestations and surgical results of malleostapedotomy and malleostapedectomy. Korean J Otorhinolaryngol-Head Neck Surg 2008;51(11):985-92.

7) Kim HJ. Classification and hearing result reporting guideline in chronic otitis media surgery. Korean J Otolaryngol-Head Neck Surg 2006;49(1):2-6

8) Aarnisalo AA, Vasama JP, Hopsu E, Ramsay H. Long-term hearing results after stapes surgery: a 20-year follow-up. Otol Neurotol 2003; 24(4):567-71.

9) Vincent R, Sperling NM, Oates J, Jindal M. Surgical findings and long-term hearing results in 3,050 stapedotomies for primary otosclerosis: a prospective study with the otology-neurotology database. Otol Neurotol 2006;27(8 Suppl 2):S25-47.

10) Pedersen CB, Elbrønd O. Large versus small fenestration technique in stapedectomy. A comparative investigation of House and Fisch prostheses in stapedectomy. Clin Otolaryngol Allied Sci 1983;8(1): 21-4.

11) Fisch U. Stapedotomy versus stapedectomy. Am J Otol 1982;4(2): 112-7.

12) Rizer FM, Lippy WH. Evolution of techniques of stapedectomy from the total stapedectomy to the small fenestra stapedectomy. Otolaryngol Clin North Am 1993;26(3):443-51.

13) Møller P. Stapedectomy versus stapedotomy: a comparison. Rev Laryngol Otol Rhinol (Bord) 1992;113(5):397-400.

14) Rothbaum DL, Roy J, Hager GD, Taylor RH, Whitcomb LL, Francis $\mathrm{HW}$, et al. Task performance in stapedotomy: comparison between surgeons of different experience levels. Otolaryngol Head Neck Surg 2003;128(1):71-7.

15) Flint PW, Haughey BH, Niparko JK, Richardson MA, Lund VJ, Robbins KT, et al. Cummings Otolaryngology-Head and Neck Surgery. Philadelphia: Elsevier Health Sciences;2010.

16) Laske RD, Röösli C, Chatzimichalis MV, Sim JH, Huber AM. The influence of prosthesis diameter in stapes surgery: a meta-analysis and systematic review of the literature. Otol Neurotol 2011;32(4): 520-8.

17) Cavaliere M, Ricciardiello F, Mesolella M, Iengo M. Stapedotomy: functional results with different diameter prostheses. ORL J Otorhinolaryngol Relat Spec 2012;74(2):93-6.

18) Wegner I, Bittermann AJ, Zinsmeester MM, van der Heijden GJ, Grolman W. Local versus general anesthesia in stapes surgery for otosclerosis: a systematic review of the evidence. Otolaryngol Head Neck Surg 2013;149(3):360-5.

19) Brackmann DE, Shelton C, Arriaga MA. Otologic Surgery. Philadelphia: Saunders/Elsevier;2010.

20) Kirtane MV, De Souza C. Otology and Neurotology. Noida: Thieme; 2013.

21) Belal A Jr, Ylikoski J. Poststapedectomy dizziness. A histopathologic report. Am J Otol 1982;3(3):187-91. 